\title{
The phagocytosis activity of isoeugenol-ester compound on Mus musculus macrophage cell
}

\author{
AWIK PUJI DYAH NURHAYATI ${ }^{1, \vartheta}$, MARDI SANTOSO ${ }^{2}$, EDWIN SETIAWAN ${ }^{1}$, DEAVINA THALITA RACHMA $^{1, v \vartheta}$ \\ ${ }^{1}$ Department of Biology, Faculty of Science, Institut Teknologi Sepuluh Nopember. Jl. Arief Rahman Hakim, Surabaya 60111, East Java, Indonesia. \\ Tel./Fax.+62-031-5963857. vemail: awik@bio.its.ac.id, awiknurhayati@gmail.com \\ ${ }^{2}$ Department of Chemistry, Faculty of Science, Institut Teknologi Sepuluh Nopember. Jl. Arief Rahman Hakim, Surabaya 60111, East Java, Indonesia
}

Manuscript received: 11 February 2019. Revision accepted: 1 June 2019.

\begin{abstract}
Authors. 2019. The activity phagocytosis of isoeugenol-ester compound on Mus musculus macrophage cell. Nusantara Bioscience 11: 117-122. Chemotherapy is drugs therapy for cancer. However, chemotherapy could damage normal cells and decrease immune system. For this reason, it is necessary to find immunostimulant compound that is able to increase immune system. Isoe ugenolester is unnatural compound that has been tested for its cytotoxicity against cancer cell and showed positive result. Nevertheless, ability of Isoeugenol-ester for inducing phagocytosis is still unknown. Therefore, bioassays study using in vitro phagocytosis were performed. Latex beads methods using antigen model in 5 isoeugenol-ester concentration series: 6,$25 ; 12,5 ; 25 ; 50$ and $100 \mu \mathrm{g} / \mathrm{mL}$ were tested to Mus musculus peritoneal macrophage cell. The optimum concentration of Isoeugenol-ester compounds in inducing phagocytosis activity of M. musculus macrophage cell was $12.5 \mu \mathrm{g} / \mathrm{mL}$.
\end{abstract}

Keywords: Immunostimulant, isoeugenol-ester, macrophage, phagocytosis

\section{INTRODUCTION}

Cancer is a disease caused by an abnormal genome that occurs due to damaged genes that regulate cell differentiation, one of the genes is gene that plays a role in regulating system of programmed cell death (apoptosis). Cancer will attack the body's immune system and it will impair immune system (Kleinsmith 2006). There are 2 kinds of immune system, that is natural (non-specific) and specific immune system (Castro et al. 2008). In nonspecific immune systems, there are cells that play a role, one of them is macrophages. Macrophages, as an effector in the immune system, contribute to destroy germs/pathogens that will damage the host (Harijanto 2000).

A good immune system will increase the number and function of Natural Killer cells that have a role as tumor suppressor so the risk of cancer will decrease by recognizing and eliminating abnormal cells or through innate immune system components (Wiharja 2016). Therefore, research on natural compounds that inducing immune system is needed due to minimize the side effects. Compounds that enhancing immune system are immunostimulant compounds (Baratawidjaja and Rengganis 2009).

Indonesia is a country with the second largest biodiversity in the world, one of the Indonesian plants used for anticancer drugs is cloves (Eugenia caryophyllata) which contains eugenol compounds that reach $70-96 \%$ (Towaha 2012). Isoeugenol (2-methoxy-4-(1-propenyl) phenol is an isomerization of eugenol compounds found in clove and cinnamon oil (Salanti et al. 2010). Based on the research of Zarlaha et al (2014) isoeugenol has IC50 value of $13.91 \mu \mathrm{g} / \mathrm{mL}$ in HeLa cancer cell, $15.57 \mu \mathrm{g} / \mathrm{mL}$ in FemX cell, $7.57 \mu \mathrm{g} / \mathrm{mL}$ in K562 cell and in SKOV3 cell has value of $23.34 \mu \mathrm{g} / \mathrm{mL}$. Isoeugenol has better cytotoxicity values than eugenol in HSG Cell Line (human submandibular gland adenocarcinoma) (Fujisawa et al. 2004) The addition of isobutyrate to the eugenol compound has higher bioactivity than the addition of butyrate, due to the presence of substituted acyl groups. In the study by Cintyasari et al. (2016), isoeugenol-ester compound induced on MCF-7 Cell Line has the ability as an anticancer compound with IC50 value of $1.671 \mu \mathrm{g} / \mathrm{mL}$. In addition, to have activity as an anticancer compound, it is expected that isoeugenol-ester compounds also have the ability as an immunostimulant compound, so it is necessary to do a research about the activity of Isoeugenol-ester compound on the induction of macrophage cell phagocytosis of mouse (Mus musculus) (Cintyasari 2016).

\section{MATERIALS AND METHODS}

\section{Place and time}

This research was done at Parasitology Laboratory, Faculty of Medicine, Gadjah Mada University (UGM), Yogyakarta, Indonesia and data processing was done at Laboratory of Zoology and Animal Engineering, Institut Teknologi Sepuluh Nopember, Surabaya, Indonesia in September-December 2017.

\section{Materials}

The materials used in this study were male Balb/C mice aged 7-8 weeks from Laboratory of Pharmacology, UGM Yogyakarta, Phosphate Buffer Saline (PBS), medium 
Roswell Park Medium Institute (RPMI), 1\% penicillinstreptomycin (Sigma), fungizone $0.5 \%$ (Caisson), DMSO (dimethyl sulfoxide), Giemsa dyes, $100 \%$ methanol, latex beads, and 2-methoxy-4-(1-propenyl) phenyl butyrate compounds.

\section{Procedures}

This research consisted of several stages, including preparation of test solution, macrophage cell isolation of mouse (M. musculus), and phagocytosis test using Latex beads model.

\section{Dilution of test solution}

The stock solution compound was prepared in concentration of $1000 \mathrm{ppm}, 1 \mathrm{~mL}$ of a 2-methoxy-4-(1propenyl) phenyl butyrate compound added with $1 \mathrm{~mL}$ DMSO (Dimethyl sulfoxide). The dilution of the test compound was stratified using RPMI (Roswell Park Medium Institute) culture medium to obtain compounds in various concentration series $(6.25,12.5,25 ; 50 ; 100$ $\mu \mathrm{g} / \mathrm{mL})$. Five tubes were prepared, the first tube filled with 3.6mL RPMI (Roswell Park Medium Institute) and the other four tubes filled with 2mL RPMI (Roswell Park Medium Institute). In the first tube was added $400 \mu \mathrm{L}$ of the compound, then from the first tube was taken $400 \mu \mathrm{L}$ of solution to be inserted into the second tube and repeated until the 5th tube. The same thing was done on the doxorubicin anti-cancer drug compound.

\section{Isolation and macrophage cell culture}

Mice were sacrificed by narcosis using chloroform. Mice placed in supine condition, abdominal skin opened and cleaned peritoneal sheathing with $70 \%$ alcohol. Mice were Injected with 10mL RPMI (Roswell Park Medium Institute), cooled down into the peritoneal cavity, awaited for approximately 3 minutes while rolling slowly. Peritoneal fluid was taken by aspiration with a syringe, then the liquid was centrifuged at $5000 \mathrm{rpm}$ for 5 minutes. The supernatant was removed, then the pellets were suspended on a complete RPMI medium (RPMI medium added with FBS (Fetal Bovine Serum) 10\%, 0.5\% fungizone amphotericin B $0.5 \%$ and $2 \%$ penicillin/ streptomycin). The number of cells was calculated by hemocytometer, then suspended with RPMI (Roswell Park Medium Institute) until obtained cell density of $2.5 \mathrm{x}$ $106 / \mathrm{mL}$. A total of $200 \mu \mathrm{L}$ of cell suspension were placed in covered pit coverslips so that each well contains 500,000 cells. Under aseptic conditions, macrophage cells were cultured on a $5 \% \mathrm{CO} 2$ incubator, $37^{\circ} \mathrm{C}$ for 30 minutes. Incubation was continued up to 24 hours after each well plus RPMI (Roswell Park Medium Institute) complete as much as $800 \mu \mathrm{L}$.

\section{Phagocytosis test with latex beads}

Wells containing macrophage cell cultures were washed with RPMI (Roswell Park Medium Institute) twice. Then added with test solution that has been suspended in complete RPMI. Mixed for 4 hours. Thereafter, the suspension was discarded and at each well added $200 \mu \mathrm{L}$ of latex beads suspension. The well was incubated for 60 minutes. After 60 minutes, the latex suspension was removed, the well was washed with PBS (Phosphate Buffer Saline) twice, fixed with $100 \%$ methanol and dried in aerated way at room temperature. The next stage was coloring with Giemsa 10\%. After being washed and dried, the coverslips were taken from the well and viewed under a light microscope at 400 times magnification then calculated the amount of latex that is phagocytosed by active macrophages. The phagocytosis index and phagocytosis capacity of the test solution were calculated by the following equation (Jensch-Junior 2006):

$$
\begin{aligned}
& \text { Phagocytosis capacity }=\frac{\text { Active Macrophage }}{\text { Total Macrophage }} \times 100 \% \\
& \text { Phagocytosis index }=\frac{\text { PhagocytoticLatex }}{\text { Active macrophage }}
\end{aligned}
$$

\section{Data analysis}

Data obtained from phagocytosis index and capacity of macrophages were tested with One Way ANOVA on SPSS software to determine the effect of Isoeugenol-ester on phagocytosis of macrophages with $95 \%$ confidence level. The analysis continued using Tukey's advanced test.

\section{RESULTS AND DISCUSSION}

\section{Results}

Morphology of macrophage cells

The morphological observation of macrophage cells was performed with compound microscope at 400x magnification using Optilab. After addition of Isoeugenolester, it showed some morphological changes the of macrophage cells, on the contrary in the control treatment did not show any morphological changes in macrophage cells. While on the provision of doxorubicin, macrophage cells are damaged in the form of necrosis.

Morphology of macrophage cells after addition of Isoeugenol compounds with various series of concentrations indicated a morphological change of cells. In cells treated by isoeugenol-ester compounds showed greater pseudopods and cytoplasmic elongation. In addition, macrophages were also able to phagocytes Latex beads more (Figure 1.B). In macrophage cells that did not add the isoeugenol-esters and doxorubicin (control) showed cell size tended to be smaller and fewer cells showed a pseudopodia elongation (Figure 1.A). This shows the state of the cell that has not been fully activated, so the latex beads in the phagocytes are relatively fewer.

\section{Phagocytosis index}

The phagocytic index is derived from the total number of latex that is phagocytosed by macrophages per number of active macrophages (Jensch-Junior 2006). The calculation Result of macrophage phagocytosis index of isoeugenol-ester compound is shown in Table 1. 

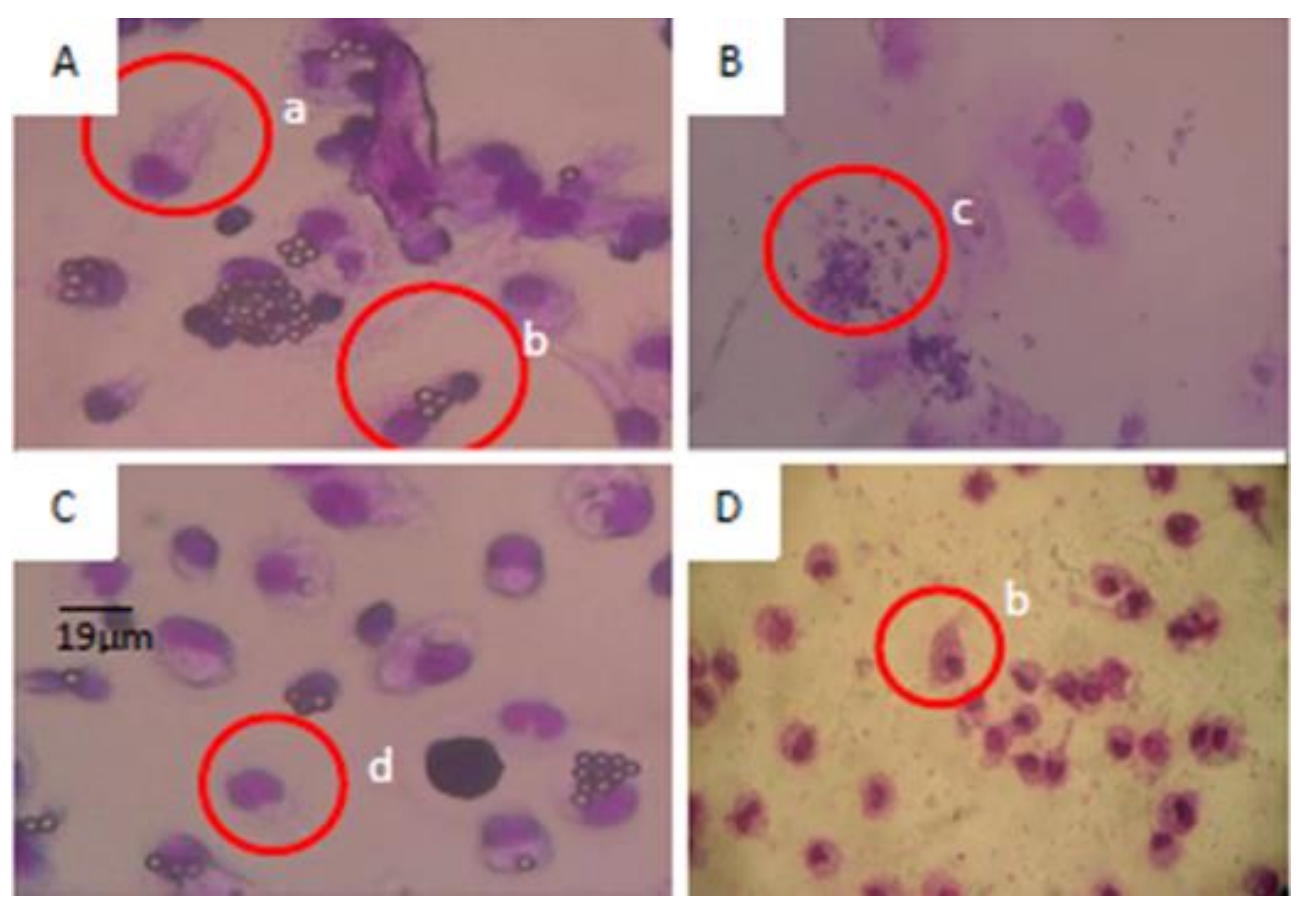

Figure 1. Morphology of mice macrophage cells (Mus musculus) after treatment of isoeugenol-ester compounds, doxorubicin, and control (without any treatment). Note: a. Activated macrophage cells, b. Macrophage cells that phagocyte Latex Beads, c. Macrophage cells that experience necrosis, d. Unaffected macrophage cells

Table 1. Phagocytosis index macrophages Mus musculus with treatment of isoeugenol-esters

\begin{tabular}{lcc}
\hline $\begin{array}{c}\text { Concentration } \\
(\boldsymbol{\mu g} / \mathbf{m L})\end{array}$ & $\begin{array}{c}\text { Phagocytotic } \\
\text { index of } \\
\text { isoeugenol-ester }\end{array}$ & $\begin{array}{c}\text { Phagocytotic index of } \\
\text { doxorubicin }\end{array}$ \\
\hline 0 & $2.629 \pm 0.392^{\mathrm{ab}}$ & $2.629 \pm 0.392^{\mathrm{b}}$ \\
6.25 & $2.274 \pm 0.582^{\mathrm{ab}}$ & $0.410 \pm 0.400^{\mathrm{a}}$ \\
12.5 & $3.707 \pm 1.165^{\mathrm{b}}$ & $0.916 \pm 0.65^{\mathrm{a}}$ \\
25 & $2.501 \pm 1.137^{\mathrm{ab}}$ & $0.375 \pm 0.105^{\mathrm{a}}$ \\
50 & $1.699 \pm 0.376^{\mathrm{ab}}$ & $0.069 \pm 0.005^{\mathrm{a}}$ \\
100 & $1.496 \pm 0.308^{\mathrm{a}}$ & $0.022 \pm 0.011^{\mathrm{a}}$ \\
\hline
\end{tabular}

Note: Different superscripts in the same column show significantly different $(\mathrm{P}<0.05)$

From Table 1 it can be seen that the lowest phagocytosis index of the Isougugol-ester compound was in the compound treatment with a concentration of 100 $\mu \mathrm{g} / \mathrm{mL}$ with an index of 1.495 . Meanwhile, the largest phagocytic index was obtained when the addition of isoeugenol-ester compound with a concentration of 12.5 $\mu \mathrm{g} / \mathrm{mL}$ of 3,707 . At an increased concentration of the isoeugenol-ester compound, the resulting phagocytosis index values showed a decrease.

\section{Phagocytic capacity}

The phagocytosis index of Mus musculus macrophages with the treatment of isoeugenol-esther compounds are shown in Table 2. From Table 2 it can be seen that the lowest phagocytic capacity of the isoeugenol-ester compound obtained in the treatment of compounds with a concentration of $100 \mu \mathrm{g} / \mathrm{mL}$ with a value of 7.22 . Whereas, the greatest phagocytic capacity of mice (M. musculus) peritoneal macrophages was in isoeugenol-ester concentration of $6.25 \mu \mathrm{g} / \mathrm{mL}$ which amounted to 34,599 . But when the concentration of Isougugol-ester compounds was increased, the resulting phagocytic capacity of macrophages decreased. The average value of doxorubicin phagocytosis capacity was lower compared to isoeugenolesters. The highest phagocytosis capacity was obtained by the addition of doxorubicin $25 \mu \mathrm{g} / \mathrm{mL}$ by 17.71 while the lowest phagocytosis capacity was obtained when doxorubicin concentration was $100 \mu \mathrm{g} / \mathrm{mL}$ at 0.94 . The addition of doxorubicin compounds started from a concentration of $6.25 \mu \mathrm{g} / \mathrm{mL}$ continued to increase in capacity values to a concentration of $25 \mu \mathrm{g} / \mathrm{mL}$. Then the value of phagocytic capacity decreased from the addition of doxorubicin $50 \mu \mathrm{g} / \mathrm{mL}$ and $100 \mu \mathrm{g} / \mathrm{mL}$.

Furthermore, data analysis was performed by One Way ANOVA statistical test using the SPSS program with a confidence level of 0.5. One Way ANOVA statistical test capacity of the isoeugenol-ester compound showed a significance value of 0.001 . This indicated that administration of isoeugenol-ester compounds has a significant influence on the capacity of macrophage phagocytosis. From the results of the Tukey test, the phagocytosis capacity of macrophages with the treatment of isoeugenol-ester compounds was divided into 2 groups of results. The first group was phagocytic capacity at concentrations of $0 \mu \mathrm{g} / \mathrm{mL}, 12.5 \mu \mathrm{g} / \mathrm{mL}, 25 \mu \mathrm{g} / \mathrm{mL}, 50$ $\mu \mathrm{g} / \mathrm{mL}$, and $100 \mu \mathrm{g} / \mathrm{mL}$, while the second group was the capacity at a concentration of $6.25 \mu \mathrm{g} / \mathrm{mL}$. From these results, it can be seen that the most significant results are phagocytic capacity at the concentration of isoeugenolester $6.25 \mu \mathrm{g} / \mathrm{mL}$. 
The results of the One Way ANOVA statistical test on the capacity of doxorubicin compounds showed a significance value of 0.000 . This suggests that the administration of doxorubicin compounds has a significant effect on the phagocytic capacity of macrophages. From the Tukey test results, phagocytosis capacity of doxorubicin compounds is divided into 2 groups. The first group was a group of compounds with concentrations of 0 $\mu \mathrm{g} / \mathrm{mL}, 50 \mu \mathrm{g} / \mathrm{mL}$, and $100 \mu \mathrm{g} / \mathrm{mL}$, while the second group was phagocytosis capacity of $0 \mu \mathrm{g} / \mathrm{mL}, 12.5 \mu \mathrm{g} / \mathrm{mL}$, and 25 $\mu \mathrm{g} / \mathrm{mL}$. The lowest phagocytic capacity of doxorubicin compounds at a concentration of $25 \mu \mathrm{g} / \mathrm{mL}$ (Table 2).

\section{Phagocytosis efficiency ratio}

Phagocytosis efficiency is the value that shows the ratio between phagocytosis index and percent phagocytosis. From the value of phagocytosis, efficiency can be seen the comparison between the capacity and phagocytosis index in each treatment concentration of compounds, so that it can be determined which concentration is more efficient.

Table 2. Capacity of phagocytosis of Mus musculus macrophages with the addition of isoeugenol-ester compounds and doxorubicin

\begin{tabular}{lcc}
\hline $\begin{array}{c}\text { Concentration } \\
(\boldsymbol{\mu g} / \mathbf{m L})\end{array}$ & $\begin{array}{c}\text { Phagocytotic } \\
\text { capacity of } \\
\text { isoeugenol-ester }\end{array}$ & $\begin{array}{c}\text { Phagocytotic } \\
\text { capacity of } \\
\text { doxorubicin }\end{array}$ \\
\hline 0 & $16.776 \pm 1.505^{\mathrm{a}}$ & $16.776 \pm 1.505^{\mathrm{b}}$ \\
6.25 & $34.599 \pm 0.569^{\mathrm{b}}$ & $9.111 \pm 0.954^{\mathrm{a}}$ \\
12.5 & $16.486 \pm 0.431^{\mathrm{a}}$ & $15.64 \pm 2.135^{\mathrm{b}}$ \\
25 & $15.816 \pm 0.471^{\mathrm{a}}$ & $17.71 \pm 1.661^{\mathrm{b}}$ \\
50 & $15.222 \pm 0.942^{\mathrm{a}}$ & $3.52 \pm 0.906^{\mathrm{a}}$ \\
100 & $7.222 \pm 1.414^{\mathrm{a}}$ & $0.94 \pm 0.930^{\mathrm{a}}$ \\
\hline
\end{tabular}

Note: Different superscripts in the same column show significantly different $(\mathrm{P}<0.05)$

Table 3. Ratio of phagocytosis of isoeugenol-ester compounds against macrophage cells of Mus musculus

\begin{tabular}{lccc}
\hline Concentration & Capacity & Index & Ratio \\
\hline $0 \mu \mathrm{g} / \mathrm{mL}$ & 16.778 & 2.629 & 0.156 \\
$6.25 \mu \mathrm{g} / \mathrm{mL}$ & 34.599 & 2.274 & 0.065 \\
$12.5 \mu \mathrm{g} / \mathrm{mL}$ & 16.486 & 3.707 & 0.224 \\
$25 \mu \mathrm{g} / \mathrm{mL}$ & 15.816 & 2.500 & 0.158 \\
$50 \mu \mathrm{g} / \mathrm{mL}$ & 15.222 & 1.699 & 0.111 \\
$100 \mu \mathrm{g} / \mathrm{mL}$ & 7.222 & 1.496 & 0.207 \\
\hline
\end{tabular}

Table 4. Ratio of phagocytosis of isoeugenol-ester compounds against macrophage cells of Mus musculus

\begin{tabular}{lccc}
\hline Concentration & Capacity & Index & Ratio \\
\hline $0 \mu \mathrm{g} / \mathrm{mL}$ & 16.778 & 2.629 & 0.156 \\
$6.25 \mu \mathrm{g} / \mathrm{mL}$ & 9.111 & 0.410 & 0.044 \\
$12.5 \mu \mathrm{g} / \mathrm{mL}$ & 15.642 & 0.910 & 0.058 \\
$25 \mu \mathrm{g} / \mathrm{mL}$ & 17.712 & 0.370 & 0.020 \\
$50 \mu \mathrm{g} / \mathrm{mL}$ & 3.525 & 0.060 & 0.017 \\
$100 \mu \mathrm{g} / \mathrm{mL}$ & 0.940 & 0.020 & 0.021 \\
\hline
\end{tabular}

From Table 3, it can be seen that the most efficient phagocytosis ratio was found in the compound concentration of $12.5 \mu \mathrm{g} / \mathrm{mL}$ with a ratio of 0.224 . It can be interpreted that with the addition of compounds with a concentration of $12.5 \mu \mathrm{g} / \mathrm{mL}$ the number of active macrophage populations is proportional to the ability of individual macrophages in phagocytosis of latex beads, or it can be said that the ratio between capacity and phagocytosis index is balanced. In the treatment using doxorubicin, the most efficient phagocytosis ratio was obtained at a concentration of $0 \mu \mathrm{g} / \mathrm{mL}$ with a ratio of 0.156 (Table 4).

From Table 4, it can be interpreted that without the addition of doxorubicin compounds, the number of active macrophage populations is proportional to the ability of individual macrophages in phagocytosis of latex beads, or it can be said that the comparative ratio of capacity and phagocytosis index is balanced.

\section{Discussion}

The elongation of pseudopodia is a form of morphological change that occurs due to macrophage activation by pathogenic microorganisms or other antigens (Mustafiah et al. 2011). The antigen used in this study was latex beads. Meanwhile, in macrophage cells treated with the addition of doxorubicin cancer drug showed a change in cell morphology that indicated the presence of necrosis. Giving doxorubicin can cause cell necrosis and cell DNA damage (Shin et al. 2012)

In the treatment with the doxorubicin compound, the phagocytic index showed a lower number when compared with the addition of the isoeugenol-ester compound. The highest phagocytosis index of doxorubicin compound was obtained in the control treatment with a concentration of 0 $\mu \mathrm{g} / \mathrm{mL}$. The phagocytosis index in the treatment with doxorubicin compounds exhibits diverse values. In normal norms before being added with doxorubicin compound, the index value of phagocytosis was 2,629. But when treated with doxorubicin, not all concentrations were able to induce macrophage activity. The most efficient concentration was obtained in the treatment of doxorubicin compound with a concentration of $12.5 \mu \mathrm{g} / \mathrm{mL}$. While at other concentrations, the level of activation of $M$. musculus macrophage cells is still low. Then performed statistical test One Way ANOVA using SPSS program with level of trust 0.05 . The results of statistical tests show a significance value of 0.042 . So the treatment using isoeugenol-ester compound showed a significant effect on the increase of macrophage phagocytosis index $(\mathrm{P}<0.05)$. Then the test continued using Tukey test. From the Tukey test result, macrophage phagocytosis index with isoeugenol-ester compound treatment was divided into 3 groups of results. The first group was phagocytic capacity at concentrations of $0 \mu \mathrm{g} / \mathrm{mL}, 6.25 \mu \mathrm{g} / \mathrm{mL}, 25 \mu \mathrm{g} / \mathrm{mL}$, and $50 \mu \mathrm{g} / \mathrm{mL}$. The second group is the index at a concentration of $12.5 \mu \mathrm{g} / \mathrm{mL}$, and group 3 , which is in the phagocytosis index concentration of $100 \mu \mathrm{g} / \mathrm{mL}$. From these data, it can be seen that the most significant results are phagocytic capacity at $12.5 \mu \mathrm{g} / \mathrm{mL}$ and $100 \mu \mathrm{g} / \mathrm{mL}$ of isoeugenol-ester. (Table 1). 
In the treatment with the doxorubicin compound, One Way ANOVA statistical test results show a significance value of 0.000 . This indicates a significant influence on the treatment with doxorubicin compounds. Then proceed with Tukey test. From the results of the Tukey test, the phagocytosis index of the doxorubicin compound is divided into 2 groups. The first group is a group of compounds with a concentration of $0 \mu \mathrm{g} / \mathrm{mL}$, while the second group is concentration $6.25 \mu \mathrm{g} / \mathrm{mL}, 12.5 \mu \mathrm{g} / \mathrm{mL}, 25$ $\mu \mathrm{g} / \mathrm{mL}, 50 \mu \mathrm{g} / \mathrm{mL}$, and $100 \mu \mathrm{g} / \mathrm{mL}$. From these results, it can be seen that the most significantly different phagocytosis index of doxorubicin compounds was obtained at concentrations of $0 \mu \mathrm{g} / \mathrm{mL}$ (control). The increase in phagocytosis index in the administration of compounds with a concentration of $12.5 \mu \mathrm{g} / \mathrm{mL}$ can provide an illustration of the effect of the Isougeno-ester compound on the immune response. It is suspected that the compound isoeugenol-ester acts as an immunostimulant so as to increase metabolism in macrophage cells. Increased metabolism in the cells will increase the enzymes that play a role in the mechanism of phagocytosis so that the ability of phagocytosis will increase (Nopitasari et al. 2006).

At the concentration of $12.5 \mu \mathrm{g} / \mathrm{mL}$, isoeugenol-ester compounds are thought to be able to activate macrophage cells to phagocytocyte latex beads, but activation has not reached the maximum stage or in other words, the isoeugenol-ester compound is capable of activating cells but only a small number of macrophage cells. In addition to having immunostimulant effects, phenolic compounds also have immunosuppressant effects, one example is the compound flavonoid group. The presence of cytotoxic and immunosuppressant effects allows for inhibition of macrophage phagocytosis activity at certain dosage limits (Makiyah et al. 2016).

Isoeugenol-ester compounds can affect macrophage activity by increasing the production of Nitric Oxide (NO), and increase the secretion of pro-inflammatory cytokines such as Interleukin (IL)-12, Interleukin (IL)-6 at low doses $(0.001-100 \mu \mathrm{g} / \mathrm{mL})$, and decrease the production of TNF $\alpha$. But at high doses between $100-1000 \mu \mathrm{g} / \mathrm{mL}$ the compound will have high cytotoxicity. In addition, isoeugenol-ester compounds can act as a Free Radical Scavenger. Although without stimulation from Lipopolysaccharide (LPS) from bacteria and apoptotic bodies, the Isougugol-ester compound is able to stimulate macrophage cells at low concentrations, but when the concentration continues to be added, the stimulus effect of the compound will not only disappear, but cell growth will also be inhibited (Dibazar et al. 2015). Isoeugenol-ester compounds are also able to improve phagocytic function of macrophage cells by increasing the production of Reactive Oxygen Species (Kamadatu et al. 2015). ROS functions to destroy DNA antigens at the degradation stage. Latex beads given as antigens will be recognized by macrophages through receptors located on the surface of macrophage receptors, one of which is MARCO (Macrophage Receptor with Collagenous Structure). MARCO is a group of macrophage receptor Scavenger that is able to recognize unopsonized particle and latex beads (Kanno et al. 2006). After the introduction of the particles by the MARCO receptor, latex beads will make the plasma membrane indentation for the ingestion stage and be followed by phagolysosome formation (Cervantez et al. 2014).

Isoeugenol-ester compounds induce phagocytic activity of macrophage cells Mice (M. musculus) were most efficiently obtained at a concentration of $12.5 \mu \mathrm{g} / \mathrm{mL}$ with an efficiency ratio of 0.156 . While doxorubicin compounds are not able to induce phagocytosis of macrophage cells.

The conclusion of this study is that the fungi identified were isoeugenol-ester compounds induced phagocytic activity of macrophage cells. The most efficient mice $(M$. musculus) was obtained at a concentration of $12.5 \mu \mathrm{g} / \mathrm{mL}$ with an efficiency ratio of 0.156 . While doxorubicin compounds were not able to induced phagocytosis of macrophage cells.

\section{ACKNOWLEDGEMENTS}

We wish to thank many people supporting this research as follows: Research grant from the Ministry of Research and Technology (i). The Chairman of the Research Institution of Sepuluh November Institute of Technology (ii).

\section{REFERENCES}

Baratawidjaja K, Rengganis I. 2009. Imunologi Dasar $8^{\text {th }}$. Balai Penerbit Fakultas Kedokteran Indonesia, Jakarta. [Indonesian]

Castro AA, Rodriguez F, De ta F, Espinosa LM, Poveda JB, Andrada M, Herraez P. 2008. Correlating the immune response with the clinical pathological course of persistent mastitis experimentally induced by Myocoplasma agalactiae in dairy goats. Res Vet Sci 12: 102-111

Cervantez JL, Kelly LH, Sarah JB, Bennet W, Stephania ML, Juan CS. 2014. Phagosomal TLR signaling upon Borrelia burgdorferi Infection. Front Cell Infect Microbiol 4 (55): 1-12.

Cintyasari A. 2016. Uji Sitotoksisitas Isoeugenol dan Tiga Isoeugenolester Terhadap Kanker Payudar MCF-7 Cell Line. [Thesis]. Institut Teknologi Sepuluh Nopember, Surabaya. [Indonesian]

Dibazar SP, Shirin F, Saeed D. 2015. Immunomodulatory effects of clove (Syzygium aromaticum) constituent on macrophages: in vitro evaluation of aqueous and ethanolic components. J Immunotoxicol 12 (2): 121-131.

Fujisawa S, Atsumi T, Ishihara M, Kadoma Y. 2004. Cytotoxicity, ROSgeneration activity and radical-scavenging activity of curcumin and related compounds. J Anticancer Res 24 (2): 563-569.

Harijanto PN. 2000. Malaria Epidemiologi, Patogenesis, Manifestasi Klinis, dan Penanganannya. Penerbit Buku Kedokteran EGC, Jakarta. [Indonesian]

Jensch-Junior BE, Pressinotti LN, Borges JC, da Silva JRM. 2006. Characterization of macrophage phagocytosis of the tropical fish Prochilodus scrofa. Aquaculture 251 (2): 509-515.

Kamadatu L. 2015. Turunan 2-metoksi-4-(prop-2enil)fenol dan (E)-2metoksi-4-(prop-1-enil)fenol: Sintesis dan Sitotoksisitas Terhadap Sel Kanker Payudara MCF-7 [Thesis]. Institut Teknologi Sepuluh Nopember, Surabaya. [Indonesian]

Kanno S, Akiko F, Seishiro H. 2006. A murine scavenger receptor MARCO recognizes polystirene nanoparticle. Toxicol Sci 97 (2): 398-406.

Kleinsmith LJ. 2006. Principles of Cancer Biology. Pearson Education. Michigan USA.

Makiyah Al, Usep AH, Ramlan S. 2016. Efek imunostimulasi ekstrak etanol umbi iles-iles terhadap aktivitas fagositosis sel makrofag pada tikus putih strain wistar yang diinokulasi Staphylococcus aureus. Majalah Kedokteran Bandung 48 (2): 68-77. [Indonesian] 
Mustafiah SE, Dina I, Iwang Y. 2011. Indeks daya fagosit makrofag peritonium setelah pemberian propolis pada mencit (Mus. musculus) Propolis Sebagai Imunomodulator 3 (2): 121-128. [Indonesian]

Nopitasari RR, Dyah. 2006. Pengaruh Pemberian Ektrak Buah Phaleria papuana terhadap Aktivitas Fagositosis Makrofag Mencit Balb/c. Fakultas Kedokteran Universitas Diponegoro, Semarang. [Indonesian]

Salanti A, Orlandi M, Tolppa EL, Zola I. 2010. Oxidation of isoeugenol by salen complexes with bulky substituents. Intl J Mol Sci 11: 912926.
Shin HJ, Kwon HK, Lee HJ, Gui X, Achek A, Kim JH, Choi S. 2015. doxorubicin-induced necrosis is mediated by-poly-(ADP-ribose) polymerase 1 (PARP) but is independent of P53. Sci Rep 5: 1-17.

Towaha J. 2012. Manfaat Eugenol Cengkeh dalam Berbagai Industri di Indonesia. Perspektif 11 (2): 79-90. [Indonesian]

Wiharja A. 2016. The New Perspective of Exercise Breast Cancer Therapy. Journal of Medicine and Health 1 (3): 288-295.

Zarlaha A, Kourkoumelis N, Stanojkovic D, Dimertzi K. 2014. Cytotoxic activity of essential oil and extracts of Ocimum basilicum against human carcinoma cells, molecular docking study of isoeugenol as a potent cox and lox inhibitor. Digest J Nanomater Biostruct 9 (3): 907917. 